Identifikasi Potensi Cekungan Air Tanah Di Universitas Sam Ratulangi Menggunakan Eksplorasi Geolistrik Tahanan Jenis

\author{
As'aria*, Seni Herlina J. Tongkukuta \\ aJurusan Fisika, FMIPA, Unsrat, Manado
}

\begin{tabular}{lll}
\hline K A T A K U N C I & & A B S T R A K \\
\cline { 3 - 4 } & Peningkatan pembangunan gedung-gedung di Kampus Universitas Sam
\end{tabular}

Wenner-Schlumberger

Ratulangi akan berdampak pada proses peresapan air ke dalam tanah, dan akan mempengaruhi siklus hidrologi di bawah permukan tanah. Kebutuhan air tanah semakin meningkat dari tahun ke tahun. Telah dilakukan pemetaaan untuk memperoleh potensi cekungan lapisan pembawa air tanah dengan arah Utara - Selatan di Kampus Universitas Sam Ratulangi Manado. Pengukuran menggunakan metode geolistrik tahanan jenis konfigurasi Wenner-Schlumberger. Pengukuran dilakukan pada 5 lintasan, 48 elektroda dan spasi elektroda $10 \mathrm{~m}$, menggunakan resistivitymeter MAE X612 EM. Data pengukuran diolah menggunakan software RES2DINV, hasil pengolahan berupa tampang lintang 2 dimensi. Akuifer air tanah dengan resistivitas $\leq 10 \Omega \mathrm{m}$, potensi akumulasi akuifer air tanah besar ditemukan di : lintasan 1 pada elektroda ke 24 - 35 (meter ke 240 - 350)dengan kedalaman $\geq 20 \mathrm{~m}$, lintasan 2 pada elektroda 23 - 30 (meter ke 230 - 300) dengan kedalaman 5 - 25 m.

K E Y W OR D S

Groundwater

Wenner-Schlumberger
A B S T R A C T

Improvement of the construction of buildings on Sam Ratulangi University Campus will have an impact on the process of infiltration of water into the soil, and will affect the hydrologic cycle under the subsurface. The need for groundwater is increasing from year to year. Has been mapped to obtain potention of the basin layer of ground water carrier in the North-South direction at the Campus of the University of Sam Ratulangi Manado. Measurements using the resistivity geoelectric method of the WennerSchlumberger configuration. Measurements were made on 5 lines, 48 electrodes and $10 \mathrm{~m}$ spaced electrodes, using a resistivitymeter MAE X612 EM. The measurement data is processed using RES2DINV software, the result of processing is 2-dimensional cross-section. Ground water aquifer with resistivity $\leq 10 \Omega \mathrm{m}$, the potential for large groundwater aquifer accumulation is found in: line 1 at 24 to 35 electrodes (meters to 240 350) with a depth of $\geq 20 \mathrm{~m}$, line 2 at 23-30 electrodes (meters to 230 300) with a depth of $5-25 \mathrm{~m}$.

\section{TERSEDIA ONLINE}

1 Agustus 2017

\section{Pendahuluan}

Air sebagai salah satu kebutuhan mendasar bagi kehidupan manusia, memerlukan pengelolaan yang baik. Air mengalir menurut siklusnya, manusia memanfaatkan air terutama pada saat siklus hidrologi berupa airtanah. Air yang langsung mengalir di permukaan bumi tersebut ada yang mengalir ke sungai, sebagian mengalir ke danau, dan akhirnya kembali ke laut. Sementara itu, air yang meresap ke bawah permukaan bumi melalui dua sistem, yaitu sistem air tidak jenuh (vadous zone) dan sistem air jenuh. Sistem air jenuh adalah air bawah tanah yang terdapat pada suatu lapisan batuan dan berada pada suatu cekungan air tanah. Sistem ini dipengaruhi oleh kondisi geologi,

*Corresponding author: Jurusan Fisika FMIPA UNSRAT, Jl. Kampus Unsrat, Manado, Indonesia 95115; Email address: as.ari2222@yahoo.co.id Published by FMIPA UNSRAT (2017) 
hidrogeologi, dan gaya tektonik, serta struktur bumi yang membentuk cekungan air tanah tersebut. Air ini dapat tersimpan dan mengalir pada lapisan batuan yang kita kenal dengan akuifer (aquifer) (Hadian dan Abdurahman, 2006).

Sadjab, dkk. 2012 memetakan keberadaan akuifer air tanah di kecamatan Prambanan Kabupaten Sleman Daerah Istimewa Yogyakarta berdasarkan resistivitas batuan bawah permukaan hasil eksplorasi geofisika dengan metode geolistrik tahanan jenis oleh As'ari 2009..

As'ari dan Seni, 2016. Telah meneliti keberadaan akuifer air tanah di Unsrat dalam arah Timur-Barat, penelitian dengan menggunakan eksplorasi geolistrik resistivitas, akuifer air tanah dengan resistivitas $\leq 7,5 \Omega \mathrm{m}$, diperoleh posisi akumulasi akuifer air tanah potensial pada: 1.Lintasan 1 elektroda ke 26 - 30 dengan kedalaman $11 \mathrm{~m}$ - $48 \mathrm{~m}$ (akuifer 1 ), pada elektroda ke 35 - 39 dengan kedalaman $\geq 6 \mathrm{~m}$ (akuifer 2). 2.Lintasan 3 pada posisi elektroda ke 16 - 19 dengan kedalaman 11 - 39 m (akuifer 1), pada elektroda ke 24 - 29 dengan kedalaman 6 - 44 m (akuifer 2). Penelitian lanjutan dengan arah yang me'lintang' perlu dilakukan sebagai langkah lanjutan untuk melengkapkan peta akuifer dalam arah Utara-Selatan.

Universitas Sam Ratulangi sebagai bagian dari masyarakat Kota Manado sudah selayaknya juga mempunyai tata pengelolaan air yang berkelanjutan. Pembangunan gedung-gedung kampus akan berdampak pada proses penyerapan air ke dalam tanah, dan akan berpengaruh pada siklus hidrologi di bawah permukan. Sementara kebutuhan airtanah akan semakin meningkat dari tahun ke tahun. Penyebaran airtanah di kampus ini tidak merata, terdapat tempat-tempat yang keberadaan air tanahnya dangkal, dalam bahkan tempat tertentu tidak ditemukan air tanah. Terhadap hal demikian dibutuhkan pemetaan akuifer air tanah secara menyeluruh di lingkungan Kampus Unsrat.

\section{Material dan Metode}

Penelitian menggunakan eksplorasi geolistrik tahanan jenis, survei ini merupakan metode eksplorasi geofisika yang ramah lingkungan dan bersifat tidak merusak. Akuisisi data dilaksanakan dengan menginjeksikan arus listrik ke dalam permukaan tanah melalui dua buah elektroda arus A dan B. Besaran yang terekam berupa beda potensial listrik yang terukur melalui dua buah elektroda potensial $\mathrm{M}$ dan $\mathrm{N}$. Eksplorasi lateral atau mapping dalam konfigursi Wenner, spasinya tetap dan keempat elektroda bergerak bersamaan sepanjang lintasan (Telford, dkk., 1990). Eksplorasi dengan konfigurasi Schlumberger ditujukan untuk mengetahui kondisi lapisan tanah bawah permukaan secara vertikal. Data yang yang terekam dari pengukuran ini berupa kuat arus (I), beda potensial (V) dan jarak spasi a. Konsep lebih teknis matematis dipaparkan dalam Parasnis, (1997).
Pada penelitian ini akuisisi data dilakukan dengan menggunakan metode geolistrik tahanan jenis konfigurasi Wenner-Schlumberger.

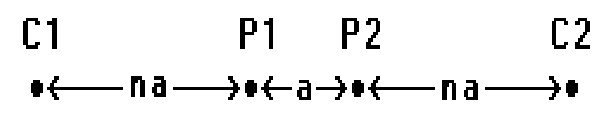

Gambar 1 Susunan elektroda konfigurasi WennerSchlumberger

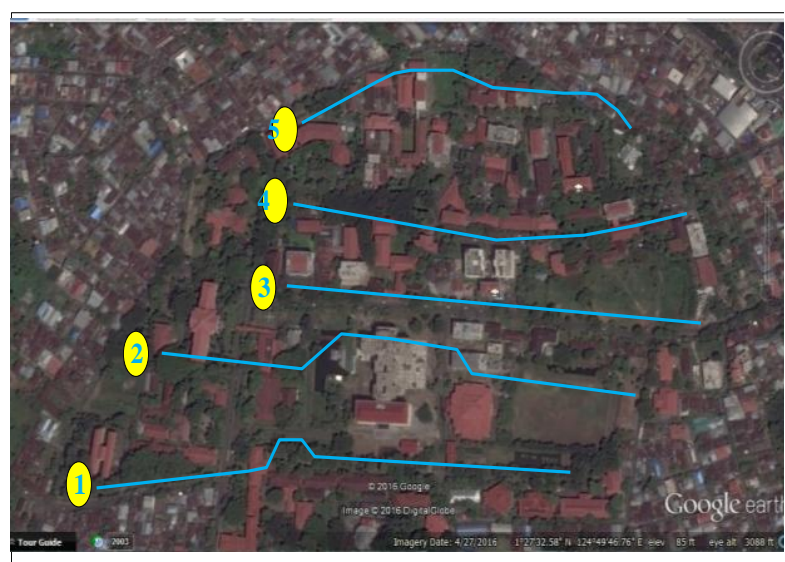

Gambar 2 Lintasan pengukuran di area Universitas Sam Ratulang

Penelitian dilaksanakan di Kampus Universitas Sam Ratulangi. Pengambilan data dilakukan pada 5 lintasan. Panjang setiap lintasan adalah $480 \mathrm{~m}$, dengan spasi antar elektroda $10 \mathrm{~m}$, digunakan 48 buah elektroda. Lintasan pengukuran terdapat Gambar 2.

\section{Hasil dan Pembahasan}

Data yang diperoleh dari pengukuran diolah menggunakan software RES2DINV, menghasilkan gambar tampang lintang 2 dimensi kontur resistivitas. Diperoleh perkiraan keberadaan lapisan pembawa air yang beragam pada tiap lintasan. Kondisi geologi daerah penelitian terdiri atas tanah liat, tanah pasiran dan batu-batu besar yang terbenam dalam tanah.

Lintasan 1 memperlihatkan keberadaan akuifer di beberapa tempat, seperti Gambar 3

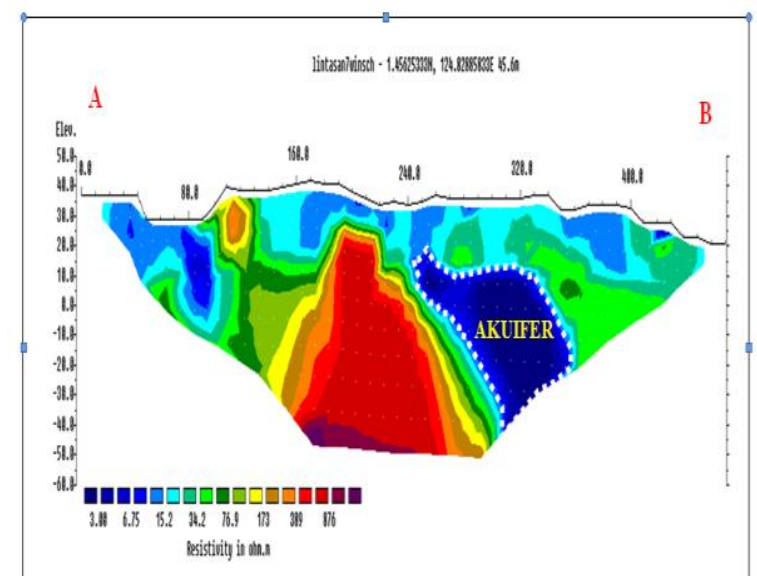

Gambar 3 Tampang lintang resistivitas bawah permukaan lintasan 1 
Lapisan tanah pembawa air tanah tampak Gambar 4, akuifer air tanah teridentifikasi dengan resistivitas $\leq 10 \Omega \mathrm{m}$,. Kantong akuifer air tanah terlihat pada meter ke 75 - 95 dengan kedalaman $5-25 \mathrm{~m}$. Potensi akuifer air tanah yang mempunyai volume besar ditemukan pada elektroda ke 24 - 35 dengan kedalaman $\geq 20 \mathrm{~m}$. Sedang lapisan tanah dengan resistivitas $10<\rho \leq 15,2 \Omega$ m merupakan lapisan penyangga, yang berarti lapisan ini mengandung air tanah tetapi akan mengalami pasang surut dan mempunyai debit kecil. Jika pada musim hujan akan naik dan sebaliknya pada musim kemarau air akan menyusut atau surut.

Tampang lintang resistivitas lintasan 2 terlihat pada Gambar 4.

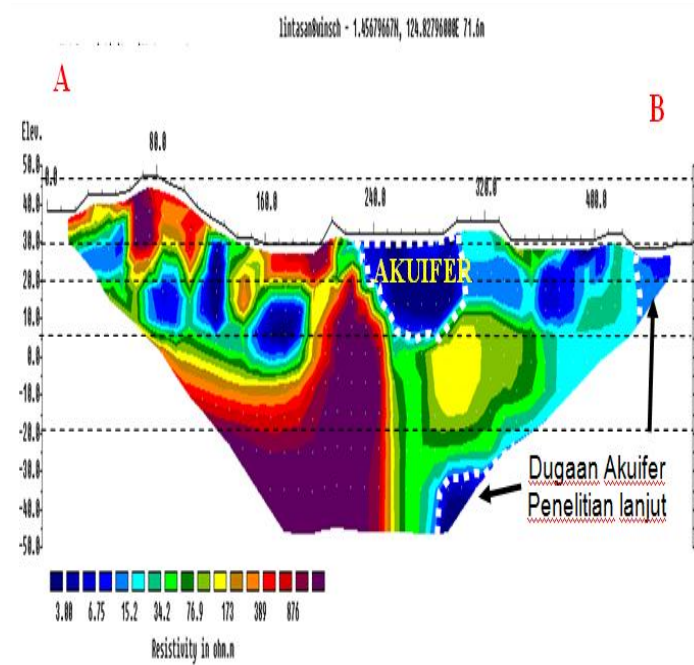

Gambar 4 Tampang lintang resistivitas bawah permukaan lintasan 1

Tampang lintang lintasan 2 pada Gambar 4 memperlihatkan beberapa lokasi akuifer air tanah. Lokasi akuifer terdapat antara elektroda ke 7 - 10 (meter ke 75-95) dengan kedalaman 25 - 35 m, elektroda ke 11 - 13 (meter ke 110-130) dengan kedalaman 5 - $25 \mathrm{~m}$, dan elektroda ke 15 - 19 (meter ke 150-190) dengan kedalaman 15 - $30 \mathrm{~m}$, pada elektroda 23 - 30 (meter ke 230 - 300) dengan kedalaman 5 - $25 \mathrm{~m}$, pada elektroda 36 41 (meter ke 360 - 410) dengan kedalaman 5 - 20 $\mathrm{m}$. Terlihat bahwa akuifer 4 mempunyai cadangan volume air yang terbesar diikuti oleh akuifer 5 . Selain itu pada lintasan 2 ini juga terdeteksi akuifer air tanah dalam tapi hanya sebagian saja, akuifer ini terdeteksi mulai pada elektroda 28 (meter ke 280) dan seterusnya pada kedalaman mulai dari $50 \mathrm{~m}$, akuifer air tanah dalam ini diperkirakan berukuran besar.

Pada lintasan 3 diperoleh sebuah akuifer dengan akumulasi air tanah dalam jumlah kecil, dan tidak teridentifikasi akuifer air tanah yang potensial dijadikan sebagai sumber penyedia air tanah. Pada lintasan 4 tidak teridentifikasi lapisan tanah pembawa air tanah.

Pada lintasan 5 tidak ditemukan akumulasi air tanah dalam jumlah besar, akuifer kecil terdapat pada tempat. potensi volume air tanah yang potensial tidak ditemukan pada lintasan 5 ini.

\section{Kesimpulan}

Telah dilakukan pemetaaan untuk memperoleh potensi cekungan lapisan pembawa air tanah dengan arah Utara - Selatan di Kampus Universitas Sam Ratulangi Manado. Pengukuran menggunakan metode geolistrik tahanan jenis konfigurasi WennerSchlumberger. Pengukuran dilakukan pada 5 lintasan, 48 elektroda dan spasi elektroda $10 \mathrm{~m}$, menggunakan resistivitymeter MAE X612 EM. Data pengukuran diolah menggunakan software RES2DINV, hasil pengolahan berupa tampang lintang 2 dimensi. Akuifer air tanah dengan resistivitas $\leq 10 \Omega \mathrm{m}$, potensi akumulasi akuifer air tanah besar ditemukan di : lintasan 1 pada elektroda ke 24 - 35 (meter ke 240 - 350)dengan kedalaman $\geq 20 \mathrm{~m}$, lintasan 2 pada elektroda 23 30 (meter ke 230 - 300) dengan kedalaman 5 - 25 $\mathrm{m}$.

Daftar Pustaka

As'ari dan Seni, H. T., 2016, Pemetaan Akuifer di Unsrat dalam Pengelolaan Sumberdaya Air Tanah Secara Berkelanjutan. Prosiding, UNHAS Makassar.

As'ari, 2009, Pemetaaan Paleo-Morfologi Abad VIII di Kompleks Candi Prambanan dengan Menggunakan Metode Geolistrik, Tesis, UGM Yogyakarta

Hadian, M.S.D., dan Abdurahman, O. 2006. Sebaran Akuifer dan Aliran Air Tanah di Kecamatan Batuceper dan Kecamatan Benda Kota Tangerang, Provinsi Banten. Jurnal Geologi Indonesia. 61: 115-116.

Parasnis, D.S., 1997, Principles of Geophysics, $5^{\text {th }}$ ed., Chapman \& Hall, London

Sadjab, B. A. 2012. Pemetaan Akuifer Air Tanah di Kecamatan Prambanan Kabupaten Sleman Daerah Istimewa Yogyakarta dengan Menggunakan Metode Geolistrik Tahanan Jenis. Skripsi. FMIPA Unsrat.

Telford, W M., Geldart, L. P., Sheriff,R. E., 1990, Applied Geophysics, Second Edition, Cambridge and Hall, New York. 